\title{
THE INITIAL DEVELOPMENT OF RURAL TOURISM DESTINATION IMAGE FROM RESIDENTS' PERCEPTIONS
}

\author{
SHERRYMINA KICHIN ${ }^{1}$, NORAZIRAH AYOB ${ }^{2}$ AND JATI KASUMA ${ }^{3 *}$ \\ ${ }^{I}$ Faculty of Hospitality \& Tourism Management, UCSI University, Malaysia. ${ }^{2}$ Faculty of Economics and Business, Universiti \\ Malaysia Sarawak, Malaysia. ${ }^{3}$ Faculty of Business and Management, Universiti Teknologi MARA, Malaysia.
}

*Corresponding author: sherrymina@ucsiuniversity.edu.my

Submitted final draft: 23 September $2020 \quad$ Accepted: 4 October $2020 \quad$ http://doi.org/10.46754/jssm.2021.07.018

\begin{abstract}
Past studies have shown that the formation of a destination image was usually perceived by tourists rather than local residents themselves. Hence, this paper aims to address the gap by demonstrating that the initial formation of cognitive and affective images of a rural tourism destination should be first investigated from its local residents' perceptions, not the tourists. In order to attain this goal, a model of destination images that place importance of the initial phase of destination image formation as perceived by its local residents was developed. A qualitative research was carried out using a sample of 100 local residents in Kampung Buntal, Sarawak, Malaysia, employing a sentence completion method, one of the projective techniques that are rarely used in mainstream destination image studies. The data were analysed using descriptive statistics and content analysis. Results indicated that the three main cognitive images of Kampung Buntal were natural environment/touristic attractions, local people and ambience, and local infrastructure. The three main positive-affective images of Kampung Buntal were pleasant, arousing, and relaxing. Using this empirical finding, tourism developers or marketers could gain better insights on the right destination images that could capture the real essence of a rural destination during promotion and marketing.
\end{abstract}

Keywords: Affective, cognitive, destination image, residents' perception, rural tourism.

\section{Introduction}

Effective destination image development plays an imperative function in tourism destination marketing. As mentioned by Kim and Chen (2016), the destination image is considered as one of the valuable concepts that contribute to the total accomplishment of a destination. Destination image can be defined as an interactive framework that depends on an individual or groups' objective knowledge, abstract impressions, prejudices, imaginations and emotional thoughts towards a destination (Alonso-Dos-Santos et al., 2014). It is basically a mental representation that is formed in a person's minds during their travel.

Developing a destination image is essential as it enables tourism marketers (supply-side) to manipulate visitors' (demand-side) decisionmaking and destination options (Tasci \& Gartner, 2007; Chen \& Tsai, 2007; Lopes, 2011; Bruwer \& Lesschaeve, 2012; Elliot \&
Papadopoulos, 2015). This is due to many tourism destinations in the marketplace are based on visitors' perceived images (Martin \& Bosque, 2008), and this situation might create a problem as those images may not reflect the true images of a particular destination. Jaafar et al. (2020) mentioned that mismatched images that are promoted for the actual destination experience could have a great impact on the tourism economies in the area. In this sense, the supply-side, such as tourism marketers (residents, local authorities, marketing agencies or government), must be able to develop the right and actual destination images before it could even be communicated and promoted to the demand-side. Besides, as intense competition in the tourism industry has caused many players to come out with creative and successful brand images, the ability to differentiate themselves relative to the competitors in the industry is vital to ensure that a particular tourism destination is able to affect visitors' decision-making process. 
Apart from that, destination images also enable future behavioural intentions, such as revisit intention and willingness to recommend the destination to other visitors (Chen \& Tsai, 2007; Lopes, 2011). A tourism destination relies on positive feedback from visitors as it could lead to future visitations, as well as attract other visitors through positive recommendations (Agapito et al., 2013). Hence, revisiting and recommending behaviours are pivotal to attain growth in destination tourism development (Chen \& Tsai, 2007).

However, destination image studies have normally concentrated on the perceptions of tourists instead of residents of a destination. Ryan and Aicken (2010) stated that residents and visitors would have different destination images. A research done by Hunter and Suh (2007) pointed out that residents tend to produce more accurate interpretations of the destination compared with visitors. Literature review showed that the perspectives of residents, which should be vital to the rural tourism development, remain underrepresented in existing researches on destination image (Stylidis et al., 2014). To local residents, a tourism destination is actually beyond than just a business focus centre where they could earn a living (Stylidis et al., 2014). In fact, it is also a place where they raise a family, as well as network with other members of the community (Stylidis et al., 2014). Hence, rural destination image studies must reflect residents' local knowledge as they are the one who are going to serve as the destination ambassadors (Campelo et al., 2014). Besides that, by developing the destination image from residents' evaluations, image researchers will be able to know what residents want for the development for their home place (Elliot et al., 2011).

Not only that, the projective techniques are not widely used in tourism researches even if the techniques are said to be capable of evaluating people's opinions and emotional state towards a destination (Rakic \& Chambers, 2010; Nghiem$\mathrm{Phu}, 2014)$. It is rarely employed in mainstream tourism studies compared with physical product and social science researches, which have long used the projective techniques as a legitimate research technique (Rakic \& Chambers, 2010). Thus, in a more recent review of the destination image literature, Nghiem-Phu (2014) proposed that future studies of tourism literature should explore destination image more by using projective techniques. The ability of projective techniques to reveal unconscious feelings and attitudes of respondents (Upadhyaya, 2012) should be taken into consideration in the development of destination image as it is formed based on a set of beliefs, knowledge and feelings of a person. For this reason, it is proposed that projective techniques, particularly the sentence completion method, are an effective method to model a destination image.

Thus, there is a need for the tourism marketers and researchers to discover how locals perceive the image of their own village because they know their homes better. The objective of this study is to develop a model of destination image formation for a rural destination that begins with the perception of local residents. In order to effectively develop the destination image for the rural destination, this study will discover both cognitive and affective images as perceived by local residents using one of the projective techniques, namely the sentence completion method. This way, both components would lead to an overall, accurate and effective destination image that takes into account both residents' belief and knowledge (cognitive), as well as feelings (affective) towards the rural destination (Baloglu \& McCleary, 1999; Beerli \& Martin, 2004).

\section{Literature Review}

\section{Doxey's Irridex model as Underlying Theory}

The Irridex model as developed by Doxey (1975) proposed different levels of irritation due to the interaction between local residents and tourists in a particular destination. Linking to this study's context, this classic Irridex model acts as an underlying theory to support the basis of residents' perceptions towards the destination image of their homes. In this sense, determining the irritation level of residents would enable residents to perceive positively or 
negatively of the images of their own places or homes as a tourist destination. This theory has been applied in the works of numerous branding studies, which believe that residents tend to have positive image perceptions when they are happy about the level of tourism development in their particular area (Kwon \& Vogt, 2009; Ryan \& Aicken, 2010).

The Irridex model suggests that residents' perceptions could be categorised into four stages, namely "Euphoria", "Apathy", "Annoyance", and "Antagonism". The initial stage of the Irridex model is called "Euphoria", in which the residents show gratitude towards new visitors and new investments that are beneficial to the community. Nonetheless, as time passes, residents' perception changes into the "Apathy" stage, where they start to take advantage of the commercial activities due to increasing tourism development. The "Annoyance" stage happens when residents become more irritated by the growing numbers of tourists and more external parties, such as private entrepreneurs, public developers, and other outside commercial businesses start to take advantage of the business opportunities in that particular place. Lastly, the "Antagonism" stage refers to when residents have reached the maximum level of irritation, in which they start to overtly express irritations towards tourists verbally and physically. According to Matthew and Koshy (2016), the courses of these stages can be avoided or reduced using effective implementation of sustainable practices. This is further supported by Campelo et al. (2014), who asserted that sustainable practices could be carried out when residents actively participate in the tourism development process, such as the building of the destination image.

\section{Residents' Involvement in Destination Image Development}

A sustainable rural tourism could only be achieved when there is active involvement and support of residents. They must be prepared to contribute in the process in order to sustain the tourism-related economy. Moreover, the role that residents play is critical to ensure the success of visitors' experience considering that they are the destination ambassadors who have local knowledge on that particular area (Stylidis et al., 2014; Campelo et al., 2014). They are the ones who will demonstrate the cultural or traditional aspects of a rural tourism destination to visitors while acting as an informant who can recommend the best features and attraction of a destination (Stylidis et al., 2014). Valle et al. (2012) stated that residents' participation leads to the financial success and an increase in the competitiveness of a destination.

For residents, their place or home is something beyond a travel destination or business focus centre (Stylidis et al., 2014). In fact, it is a place where they are conceived, raise their family, associate with other networks of community, procure a living, as well as educate themselves. Therefore, it is clear that they are the one who know the destination better or have the local knowledge on what the destination could offers to visitors. With their precise understanding on the "brand identity" of the destination, image researchers could definitely develop a progressively successful and clear destination image. For these reasons, Campelo et al. (2014) unequivocally underlined that it is crucial to fuse residents' perception in the formation of the destination image because they know how to boost visitors' experience in that particular tourism destination.

Nonetheless, residents' involvement in developing the destination image for rural tourism destinations remain underrepresented, although their perspectives are equally crucial as visitors' perspectives for tourism development and destination marketing activities (Stylidis et al., 2014). There are numerous past researches that discover visitors' perception on destination image, but not from residents' point of view. Although both visitors' and residents' perceptions were equally crucial, however, it was argued by Hunter and Suh (2007), Elliot et al. (2011), Stylidis et al. (2014) and Campelo et al., (2014) that residents' perception of a destination image might produce a more accurate rendition 
or interpretation of their own place compared with that of visitors.

\section{Cognitive and Affective Components in Destination Image}

Many destination image researchers recognised that the destination image is a mixture of both cognitive and affective components (Baloglu \& McCleary, 1999; Beerli \& Martin, 2004). Unfortunately, the literature has revealed that a vast amount of existing image studies tend to neglect the affective component during the image formation process (Tasci et al., 2007; Nghiem$\mathrm{Phu}, 2014)$. Most image researchers were more inclined to discover the cognitive component compared with the affective component as the cognitive component provides clearer and more applicable information (Chen, 2001).

The cognitive component of destination image can be interpreted as a person's beliefs and knowledge about a particular destination's attributes (Pike \& Ryan, 2004; Hosany et al., 2006; Agapito et al., 2013; Zhang et al., 2014). In a study by Stabler (1988), the author claimed that the cognitive image is created based on a set of qualities or dimensions that are linked to the resources, magnetisms of the place and universal tourism offerings of the destination. Thus, attributes or dimensions of a destination have become a critical element in the cognitive evaluation of a visitor. Beerli and Martin (2004) classified nine cognitive dimensions, which are natural resources; general infrastructure; tourism infrastructure; tourism leisure and recreation; culture, history and art; political and economic factors; natural environment; social environment; and, the atmosphere.

The affective component is defined as an individual's feelings or emotions towards a specific place (Beerli \& Martin, 2004). According to Marino (2008), affective feelings emerge when an individual assesses how they feel during the destination visitation. Baloglu and McCleary (1999) embraced the ideas of Russell and Pratt (1980) on positive and negative elements of the affective component. They mentioned that the positive dimensions of affective component consist of feelings such as relaxing, pleasant, exciting and arousing, whereas, the negative elements of the affective component include distress, unpleasant, gloomy and sleepy.

However, it is believed that the destination image should only be built based on the positive dimensions of the affective image component. According to Qu et al. (2011), it is important to develop a positive image of a destination because it is the core of destination branding. This is why only positive dimensions, such arousing, exciting, pleasant and relaxing, will be used to measure the feelings of a person towards the chosen destination in this study. The negative dimensions will be eliminated since it appears to be irrelevant in the formation of a destination image.

In a more recent literature, the affective component was found to be understudied in contrast with the cognitive component (Nghiem$\mathrm{Phu}$, 2014). This statement is additionally supported by other authors who acknowledged that existing literature focuses more on cognition when evaluating the image of a destination (Tasci et al., 2007; Byon \& Zhang, 2010). According to Chen (2001), the primary purpose behind the vast focus on cognitive component in destination image studies is due to its more pertinent data, which provides more applicable information compared with the affective component. Thus, the emotional attachment that a person may have towards a destination tends to be overlooked, resulting in a less effective and less clear destination image formation. Nonetheless, expanding on the knowledge that the total destination image ought to comprise both cognitive and affective components, an effective formation model must be constructed to reveal a holistic destination image from the perspectives of rural residents.

\section{Projective Techniques as an Investigation Method of Destination Image}

In the context of destination image formation, it is particularly important to choose the best technique so that the researchers can come up 
with an effective model. Various methods have been adopted by tourism researchers to develop a destination image. Some tourism researchers used the push and pull factors model adopted from Lubbe (1998), while the others have used PATH model constructed by Baloglu and McCleary (1999), which includes three image elements, such as tourism motivation, socio-demographics and various information sources. Other methods of constructing a model of destination image can be found in the works of Beerli and Martin (2004), Tasci et al. (2007), Prayag and Ryan (2012) and so on. Despite the numerous destination image formation models that are available in literature on tourism, it is noted that most studies focused on the quantitative approach when measuring a person's cognitive and affective evaluations (Baloglu \& McCleary, 1999; Beerli \& Martin, 2004; Mendes et al., 2011). According to Upadhyaya (2012), the quantitative approach is not an appropriate technique to uncover feelings, attitudes, emotions and motivations of a respondent. This is because it often fails to allow respondents to express their entire views or feelings towards the image of a particular tourism destination. Effective destination image branding requires a deep emotional investigation instead of an analysis using a standard vocabulary on a structured scale measured by a quantitative approach (Upadhyaya, 2012; Ayob \& Kichin, 2016). Hence, this study proposed the use of projective techniques as the most appropriate method in developing the destination image formation model.

Projective techniques originated from the work of Sigmund Freud in the field of psychology. It was firstly employed in paranoia research to enable respondents to defend themselves by unconsciously projecting their negative personality attributes to other people. In 1940s, the techniques were implemented in market research to enable researchers to uncover respondents' feelings and thoughts on areas that may not be exposed via questionnaires techniques (Catterall \& Ibbotson, 2000). Hence, projective techniques are highly relevant in collecting data for destination image formation as a destination image often requires implicit justification and perceptions of knowledge from visitors (Hofstede et al., 2007). A destination image is based on visitors' own impressions and perspectives (Martin \& Bosque, 2008). Thus, projective techniques, which are part of qualitative methods, will be useful in producing more informative results, compared with the quantitative method (Hofstede et al., 2007; Upadhyaya, 2012).

In this research study, it is important to note that only one projective technique was used and that is the sentence completion method. The method is a qualitative technique that generates valuable and in-depth information from respondents (Wassler \& Hung, 2015). This is due to its unstructured, indirect form of questioning that allows respondents to complete incomplete stimulus using their own interpretation. Hence, it should be used in exploratory research due to its ability to capture a person's total impressions or evaluations towards a certain subject (Wassler \& Hung, 2015). The sentence completion method is an example of projective techniques that require respondents to complete an incomplete sentence (Putthiwanit, 2012). Respondents are generally asked to fill the gaps in sentences so that the task could be completed. This means that respondents need to complete a sentence using words or phrases that they deem appropriate (Magnini et al., 2012). Moreover, respondents also need to come up with their own interpretation as sentence completion does not provide any options to choose from (Wassler \& Hung, 2015).

Sentence completion in this research served several functions. Firstly, it encouraged respondents to reveal their underlying feelings and knowledge towards the destination image of a particular place. Thus, the sentence completion method is seen to be the most suitable method to discover cognitive and affective images. According to Putthiwanit (2012), sentence completion is able to reveal the thoughts of a respondent through the use of incomplete stimulus. When respondents fill in the blank of an incomplete sentence, they basically provide answers based on their own evaluations 
which might be affected by their own personal feelings and beliefs. Apart from that, sentence completion is useful as it allows researchers to gain spontaneous and honest answers from respondents compared with the questionnaire method (Hoyer \& MacInnis, 2007). In a sentence completion task, respondents need to use their own words to describe a destination image. These descriptions were done partly subconsciously (Soley \& Smith, 2008), which are derived from respondents' own feelings and evaluations. For this reason, it allows respondents to construe personal meanings and perceptions, which might be difficult to uncover with other types of measurements (Kujala \& Nurkka, 2012).

\section{Rural Destination Image Formation Model}

The overall rural tourist destination image model evaluated in this study is presented in Figure 1. As per the model, the underlying phase of the destination image formation process should begin by investigating the internal assessment of villagers or residents. In this stage, researchers need to determine the brand image of a destination by seeing how its local residents would want their village to be perceived by visitors. This is done by analysing their cognitive and affective evaluations, which hold the image perceptions of the residents. "Internal assessment of villagers or residents" should be the initial step of destination image formation since it is essential to acquire a precise image identification that could only come from the residents of a destination themselves (Hunter \& Suh, 2007). The image identity of a destination should be built from the perspectives of residents considering that they are the only ones who know a destination better compare with visitors (Stylidis et al., 2014). In addition, residents are the one who live in said place. Therefore, it does make sense that they possess superior information on what adestination can offer to visitors.

The next phase of rural destination image formation is the image-building stage. The stage alludes to a foundation of a specific image of one destination (Li \& Vogelsong, 2002). In this stage, researchers may create a comprehensive image of a destination by assessing residents' perception of the attributes (cognitive) and feelings (affective) towards their own village. Cognitive assessments refer residents' belief and knowledge (Agapito et al., 2013; Zhang et al., 2014). Meanwhile, affective assessments refer to residents' emotions, feelings, moods or attitudes towards their own village (Beerli \& Martin, 2004; Tasci et al., 2007; Marino, 2008). The two components ought to be viewed as vital when developing a destination image as both act as mental reactions to environmental stimuli that will formulate a dynamic and interactive system (Peter \& Olson, 1999). Henceforth, the image-building stage in this proposed model is very significant. This is principally in light of the fact that it would give an exact, effective and clear destination image identity that grasps the idea of residents' ownership over a destination. As expressed by Li and Vogelsong (2002), this initial formation phase is deemed as the most vital ones in this study because it makes the process of destination image formation and communication possible.

In this study, local residents of a rural destination in Sarawak were assessed. Subsequently, images of the destination were constructed based on their evaluations. This study only covered the initial phase of the image formation model, not the image communication and image acceptance phases. This was due to time constraints in completing the whole image formation process during the study period. Future studies may consider an exploration of image communication and image acceptance processes of a destination in a progressively definite way. By doing this, a holistic destination image formation process could be obtained.

After the initial formation of a destination image, tourism developers and marketers need to communicate the resulting image to visitors or the general public. Hence, the image communication stage refers to a process where tourism developers and marketers choose and use the right image vehicles and promotion tools (Li \& Vogelsong, 2002). This stage is also essential in the destination image formation 


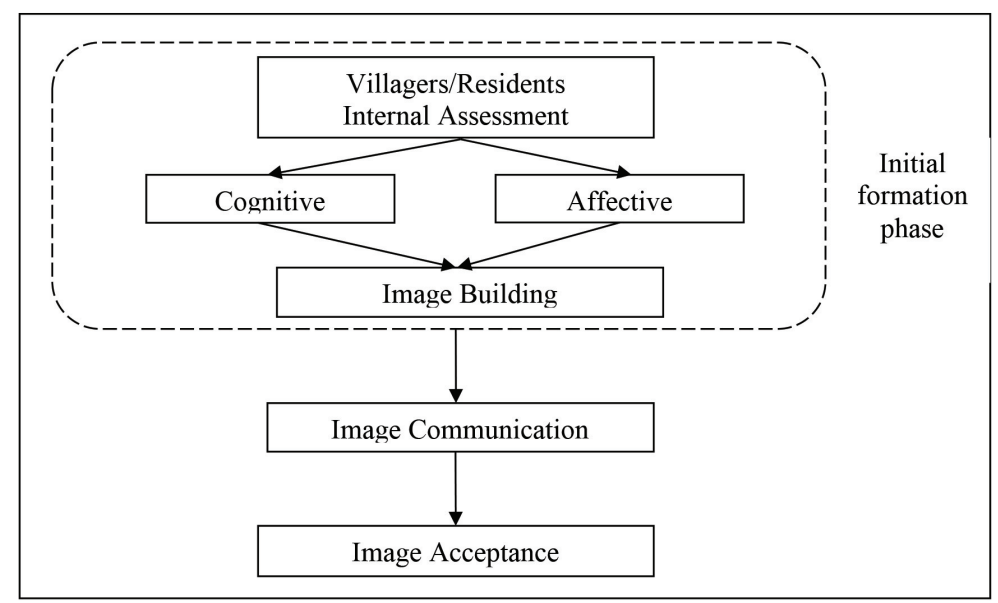

Figure 1: Phases of a rural destination image formation

process as it allows tourism developers and marketers to suggest appropriate marketing mediums. In consequence, effective marketing mediums could definitely assist residents in imparting positive image messages to the target market or visitors. According to $\mathrm{Li}$ and Vogelsong (2002), the right image vehicles have the capacity of making a destination image becomes more identifiable and accessible. In the meantime, the promotion tools bring all the image information much closer to visitors. The promotion tools could comprise of TV and radio promotions, printing materials, like brochures, maps, banners and announcement, open air media, advertising, or maybe innovation media, for example, DVDs, slides, CD-ROMs and tapes.

Following the image communication is the image acceptance stage. Image acceptance is the stage where the researchers need to reconcile the built destination image in the earlier phase to the image perspectives of visitors. As indicated by Ryan and Aicken (2010), a destination that accomplishes the condition of congruency or understanding between residents and visitors is more likely to gain positive assessments from visitors. Thus, in this stage, researchers need to evaluate whether visitors acknowledge the destination image formed by residents ( $\mathrm{Li} \&$ Vogelsong, 2002). In the event that the destination image matches visitors' discernments, they will highly likely make an attempt to visit the destination. On the contrary, visitors are likely to discard concerning information if they found that the destination image is considered unfavourable. Either way, inputs from visitors will assist in limiting the negative sentiment about the village, improve overall visitor experience while emphatically influence the cooperation between both residents and visitors. Effective destination image development plays an important role in tourism destination marketing. As mentioned by $\mathrm{Kim}$ and Chen (2016), destination image is considered as one of the valuable concepts that contribute to the overall success of a destination. Destination image can be defined as "an interactive system that is based on an individual or groups'objective knowledge, subjective impressions, prejudices, imaginations and emotional thoughts towards a destination" (Alonso-Dos-Santos et al., 2014, p.348). It is basically a mental representation that is formed in a person's minds during their travel experiences.

\section{Materials and Methods}

\section{Research Site}

Kampung Buntal is chosen as a research site for this study in order to come up with a model of destination image using projective techniques. Kampung Buntal is located in the state of Sarawak, Malaysia, and is located $27 \mathrm{~km}$ from 
the northeast of Kuching City. It represents an important rural tourism destination in Sarawak as it is a part of tourism corridor in DamaiSantubong-Buntal-Pasir Pandak (DSBP) areas. It has been recently developed into one of the mini Rural Transformation Centre (RTC) areas in Sarawak. Following the RTC development in 2013, Kampung Buntal is expected to undertake a transformation process from a fishing village to a tourist destination. The outcomes of the project are to improve the socio-economic wellbeing of the community in Kampung Buntal, as well as to enhance their standard of living. According to then Deputy Home Minister Datuk Sri Wan Junaidi Tuanku Jaafar (Veno, 2015), the Kampung Buntal area is yet to be fully opened and utilised by the local community as one of the rapid tourism destination areas, like Santubong village and the Damai area. Recognising the significance of developing a destination image, the Sarawak government has committed considerable efforts and funds towards enhancing the image and attractiveness of Kampung Buntal. Having said that, tourismrelated activities, such as homestays, seafood restaurants, bird watching, boat cruises, dolphin and mangrove tours, as well as other business activities, may be further enhanced under this transformation project. Therefore, creating an effective destination image of Kampung Buntal is essential as an effort to build the village's identity as one of the rural tourist attractions in Sarawak.

\section{Research Methodology}

This study employed a projective technique called the sentence completion method to collect data. The method was chosen due to its simple application and its ability to obtain spontaneous responses and individualist inputs from respondents (Magnini et al., 2012). The respondents in this study were 100 local residents of Kampung Buntal and this sample size was considered appropriate in qualitative research since the study was only concerned with the meaning and not generalised hypothesis statements (Mason, 2010; Rubin
\& Babbie, 2010). It is also important to note that the respondents were approached using the judgemental sampling method. This is because the respondents were selected based on researchers' judgement and were treated as representatives of 'presumably typical' population elements in the sample (Pizam, 1987).

The data collection comprised two sections, whereby the first section aims to reveal the demographic characteristics of the sample population. Meanwhile, the second section attempts to discover the cognitive and affective image components of Kampung Buntal. To examine the cognitive images of Kampung Buntal, the respondents were asked to complete Item 1, which was "My village is...". This task was meant to contextualise the overall thoughts, belief and knowledge held by a local resident towards Kampung Buntal. Using a similar method, the respondents were asked to complete Item 2, which was "I like my village because...". This item was designed to reveal affective perceptions (i.e overall feelings or emotions) that the residents have towards Kampung Buntal.

The obtained data were then analysed using two types of data analysis methods. Firstly, Section 1 of the survey was analysed using descriptive statistics (SPSS version 22). Section 2 , on the other hand, was analysed using content analysis, which comprised three procedures: (1) theme identification, (2) theme categorisation and (3) defining focus dimension. Theme identification involved the identification of any particular statements, themes or responses posed by each individual. Theme categorisation required the study to group the earlier identified statements into similar characteristics (also known as "dimension"). Lastly, "defining focus dimension" procedure was discovered in this study via incidence density analysis. "Incidence density" refers to the frequency of responses mentioned by the respondents. The analysis result of incidence density will then define the clearest and most important destination image components of Kampung Buntal. 


\section{Results}

Descriptive Analysis of Respondents' Profile

Table 1: Descriptive analysis of respondents' profile

\begin{tabular}{|c|c|c|c|}
\hline Demographic Profile & Categories & Frequency & Percentage, $\%$ \\
\hline \multirow[t]{3}{*}{ Gender } & Male & 39 & 39.00 \\
\hline & Female & 61 & 61.00 \\
\hline & Total & 100 & 100.00 \\
\hline \multirow[t]{6}{*}{ Age } & $11-20$ years old & 25 & 25.00 \\
\hline & $21-30$ years old & 23 & 23.00 \\
\hline & $31-40$ years old & 17 & 17.00 \\
\hline & $41-50$ years old & 16 & 16.00 \\
\hline & 51 years old and above & 19 & 19.00 \\
\hline & Total & 100 & 100.00 \\
\hline \multirow[t]{3}{*}{ Marital Status } & Married & 57 & 57.00 \\
\hline & Single & 43 & 43.00 \\
\hline & Total & 100 & 100.00 \\
\hline \multirow[t]{6}{*}{ Race } & Malay & 91 & 91.00 \\
\hline & Chinese & 4 & 4.00 \\
\hline & Indian & 0 & 0.00 \\
\hline & Bumiputra & 5 & 5.00 \\
\hline & Others & 0 & 0.00 \\
\hline & Total & 100 & 100.00 \\
\hline \multirow[t]{5}{*}{ Occupation } & Employed & 30 & 30.00 \\
\hline & Self-employed & 39 & 39.00 \\
\hline & Unemployed & 9 & 9.00 \\
\hline & Student & 22 & 22.00 \\
\hline & Total & 100 & 100.00 \\
\hline \multirow{3}{*}{$\begin{array}{l}\text { Years lived in Kampung } \\
\text { Buntal }\end{array}$} & Less than 10 years & 5 & 5.00 \\
\hline & 10 years and above & 95 & 95.00 \\
\hline & Total & 100 & 100.00 \\
\hline
\end{tabular}

Cognitive Images from Kampung Buntal Kampung Buntal was by analysing the whole Residents' Perspective

\section{Theme Identification}

Item 1 (“Kampung Buntal is... ”) was concerning the cognitive images of Kampung Buntal as perceived by its residents. The initial step to discover the potential cognitive themes of body of text responses manually. The findings were further supported by the authors' own observations during several visits to Kampung Buntal. In general, it can be seen that the majority of Kampung Buntal's respondents gave their answers in terms of very specific attributes or statements. As a result, there were at least 22 
identified statements (refer Table 2) regarding Kampung Buntal based on the sentence completion task responses.

It was interesting to note that the majority of the respondents mentioned "fishing village" to describe what Kampung Buntal actually is. Meanwhile, the second strongest statement regarding Kampung Buntal according to its residents was "tourist attraction". These two statements defined the clearest cognitive attributes of Kampung Buntal, which depicts what is the current belief or knowledge that the residents have about their own village. It was also fascinating to see that the residents tend to have positive images about Kampung Buntal given that the sentence completion tasks provided in the survey were able to receive negative answers.

\section{Theme Categorisation}

All of the 22 residents' statements identified earlier were then classified into five dimensions. The five dimensions were natural environment/ touristic attractions, local people and ambience, local infrastructure, socio-economics factor and local production. A number of 3 to 7 items were assigned to each of the five dimensions based on previous studies (Fakeye \& Crompton, 1991; Law, 1995; Chalip et al., 2003; Hui \& Wan, 2003; Beerli \& Martin, 2004; Obenour et al., 2005; Martin \& Bosque, 2008; Qu et al., 2011).

\section{Defining Focus Dimensions}

In order to define the focus dimensions of Kampung Buntal, the incidence density analysis as part of the content analysis procedure was performed. It was crucial to determine the frequency of statements mentioned because it defined which is the most lucid or important cognitive image dimension of the village. Table 2 presents the result of the incidence density analysis of the cognitive image components of Kampung Buntal.

\section{Affective Images from Kampung Buntal residents' perspective}

\section{Theme Identification}

Item 2 ("I like Kampung Buntal because...") was designed to discover the affective image components of Kampung Buntal as perceived by its own residents. The initial step to discover the potential affective images of Kampung Buntal was by identifying the important keywords in the whole body of text responses. The keywords were then analysed if it matched with any definition of emotions or feelings provided in the literature review. In this study context, it is important to note that the emotions or feelings were referred as the "affective image themes". There were at least 11 positive affective image themes of Kampung Buntal identified via this study (refer Table 3).

It was noticed that almost a majority of the residents agreed that they feel "glad" and "thankful" when they think about their own village. The total mentioned for these two themes were very convincing, whereby it accounted for 77 mentions out of 152 in totals $\backslash$. The very least affective image themes of Kampung Buntal were "safe and secure" as well as "amused". Besides that, it was also quite interesting to see the good response rates for this item. Some respondents described their feelings or emotions toward Kampung Buntal with up to five affective image themes.

\section{Theme Categorization}

The 11 affective image themes of Kampung Buntal discovered earlier were then classified into four positive-affective dimensions. The dimensions included pleasant, exciting, relaxing and arousing. A number of 1 to 7 items were assigned to each of the four dimensions based on previous studies (Donovan \& Rossiter, 1982; Fredrickson, 2001; Emmons \& McCullough, 2003; Hanin, 2004; Scherer, 2005; Staik, 2013). 
Table 2: Incidence density analysis result of the cognitive image components

\begin{tabular}{clccc}
\hline Items & Residents' Statements & Frequency & $\begin{array}{c}\text { Percentage } \\
(\%)\end{array}$ & $\begin{array}{c}\text { Cognitive Dimension } \\
\text { Categories }\end{array}$ \\
\hline 1 & Fishing village & 45 & 31.69 & $\begin{array}{c}\text { Natural environment/ touristic } \\
\text { attractions (69.72\%) }\end{array}$ \\
2 & Tourist attraction & 25 & 17.61 & \\
3 & Fresh seafood & 9 & 6.34 & \\
4 & Beautiful scenery & 11 & 7.75 & \\
5 & Nice beaches & 5 & 3.52 & \\
6 & Famous destination & 3 & 2.11 & \\
7 & Puffer fish & 1 & 0.70 & \\
\hline 8 & Peaceful place & 9 & 6.34 & Local people and ambience \\
9 & Fun place & 1 & 0.70 & \\
10 & Attractive place & 1 & 0.70 & \\
11 & Proud local & 4 & 2.82 & \\
12 & Friendly local & 3 & 2.11 & \\
13 & Cooperative local & 1 & 0.70 & \\
\hline 14 & Variety of facilities & 1 & 0.70 & Local infrastructure (7.04\%) \\
15 & Developing village & 6 & 4.23 & \\
16 & High potential for development & 3 & 2.11 & \\
\hline 17 & Easy to earn money & 4 & 2.82 & Socioeconomics factor (5.63\%) \\
18 & Lots of opportunity & 3 & 2.11 & \\
19 & Potential for tourism centre & 1 & 0.70 & \\
\hline 20 & Seafood restaurant & 1 & 0.70 & \\
& & & & \\
21 & Seafood market & 3 & 2.11 & \\
22 & Local vegetable market & 2 & 1.41 & \\
\hline
\end{tabular}

\section{Defining Focus Dimension}

After reviewing all of the 11 affective themes and its dimensions, the incidence density analysis was conducted (refer to Table 3). As mentioned earlier, it was crucial to find out the frequency of themes mentioned as it defined the clearest or most important affective image of Kampung Buntal. From the results, this study found out that the "pleasant" image of Kampung Buntal received the highest total percentage, which was $76.97 \%$. 
Table 3: Incidence density analysis result of the affective image components

\begin{tabular}{llccc}
\hline Items & Residents' Statements & Frequency & Percentage & $\begin{array}{c}\text { Affective Dimension } \\
\text { Categories }\end{array}$ \\
\hline 1 & Glad & 46 & $30.26 \%$ & $\begin{array}{c}\text { Pleasant } \\
(76.97 \%)\end{array}$ \\
3 & Thankful & 31 & $20.39 \%$ & \\
4 & Pride & 18 & $11.84 \%$ & \\
5 & Content & 11 & $7.24 \%$ & \\
6 & Optimistic & 6 & $3.95 \%$ & \\
7 & Comfortable & 4 & $2.63 \%$ & Arousing \\
\hline 8 & Safe and secured & 1 & $0.66 \%$ & $(12.50 \%)$ \\
9 & Lively & 12 & $7.89 \%$ & Relaxing \\
\hline 10 & Stimulating & 7 & $4.61 \%$ & $(9.87 \%)$ \\
\hline 11 & Serene & 15 & $9.87 \%$ & $\begin{array}{c}\text { Exciting } \\
\end{array}$ \\
& Amusing & & & $(0.66 \%)$ \\
\hline
\end{tabular}

\section{Discussion}

In the discussion, the study proposes top three cognitive and affective images of Kampung Buntal as those images are considered to have the strongest association with the village and largely perceived by the residents. The results indicate that those are the images most mentioned by the residents and thus, and it tends to provide most accurate images that could help Destination Marketing Organisations (DMOs) such as government agencies, travel agencies or associations to promote Kampung Buntal as an attractive travel destination. Hence, most frequent images should be pointed out more than less frequent or rare images as it provides guidance especially when the destination image of a particular place is a rare one or not immediately clear (Stepchenkova \& Shichkova, 2016) which in this study's context, refers to Kampung Buntal village.

\section{Top Three Cognitive Images of Kampung Buntal}

The cognitive images of Kampung Buntal that are most evoked by the residents are linked to the natural environment/touristic attractions component. This is no surprise considering that majority of the respondents were using attributes associated with nature or physical attractions, such fishing village, tourist attraction, fresh seafood, nice beach, beautiful scenery, or puffer fish to describe Kampung Buntal. This current finding is somewhat consistent with previous studies on residents' image perception (Schroeder, 1996; Stylidis et al., 2014) that suggested local residents value physical attributes, such as weather, scenery, sightseeing and architectural beauty. Similarly, Lin et al. (2007) asserted that the characteristic of natural elements is valued dearly in people's minds considering that this element often stimulates their enjoyment of daily activities. In the case of Kampung Buntal, it is notable that the residents put greater emphasis on the village's natural environment or touristic attractions dimension. This may be attributed to the residents' appreciation towards the nature of Kampung Buntal, which has been the place where they live, work and socialise with other community in a quite long period of time.

Another cognitive dimension of Kampung Buntal identified in this study is the local people and ambience. This dimension consisted several attribute's statements or themes of 
Kampung Buntal such as peaceful place, fun place, attractive place, proud local, friendly local and cooperative local. The "local people and ambience" dimension is somewhat akin to the dimensions of "hospitality atmosphere", "atmosphere" or "social environment" as discussed in previous studies (Hui \& Wan, 2003; Beerli \& Martin, 2004; Martin \& Bosque, 2008; Chen et al., 2013). In the case of Kampung Buntal, the findings suggested that local residents tend to greatly value peaceful, proud and friendly social environment of Kampung Buntal with minimal emphasis on other attributes. Drawn from the arguments made by Stylidis et al. (2014), residents of a smaller community tend to have strong bonds with each other. This explains why residents of Kampung Buntal perceived the village's image as such, because strong bonds enable the residence to feel more united, have a strong sense of belonging towards their own residence and more sociable.

Local infrastructure, another dimension of Kampung Buntal identified in this study, focuses on the physical systems of the village (Martin $\&$ Bosque, 2008). This dimension is somewhat similar to "community service" (Stylidis et al., 2014), "government service" (Sirgy et al., 2000) and "general infrastructure" (Beerli \& Martin, 2004). In the case of Kampung Buntal, the attribute's statements or themes that fall under this dimension comprised a variety of facilities, developing village and high potential for development. Facilities, in this sense, encapsulate the amenities related to health, education, wellbeing, transportation, communication, tourism and security issues (Sirgy et al., 2000). Based on the study results, this study suggests that the residents tend to perceive Kampung Buntal as a village that is currently developing. This may show that the residents of Kampung Buntal are increasingly aware of the government's current efforts in transforming the village from a fishing village to a tourist destination (Veno, 2015). This is quite similar to the results obtained by Stylidis et al. (2014), whereby the residents tend to value the community service dimension when they started to notice the impacts tourism development may have on the local community.

\section{Top Three Affective Images of Kampung Buntal}

With regards to the affective component, Kampung Buntal's residents at present tend to highly perceive the village as a pleasant destination. This affective dimension refers to a state of feeling pleasure and happy (Huong \& Lam, 2008), appreciated (Emmons \& McCullough, 2003; Sansone \& Sansone, 2010), fulfilled feeling of belonging (Fredrickson, 2001), satisfied (Scherer, 2005; Hufendiek, 2016), positive (Conversano et al., 2010; Staik, 2013), comfortable (Hanin, 2004; Houck, 2007) or protected (Staik, 2013; Spiekermann, 2016). In the case of Kampung Buntal, most respondents tend to characterise their pleasant feelings towards the village as "glad", "thankful", "pride", "content", "optimistic", "comfortable" as well as "safe and secure".

As argued by Moutinho (1987), affective evaluation comes after assessing the cognitive perception. In this study, it is notable that the feelings of Kampung Buntal's residents towards the village are formed based on their cognitive perceptions. For instance, 31 study respondents mentioned that they like Kampung Buntal because they are thankful for the abundance of sustenance provided by that village. Additionally, $30.26 \%$ agreed that they feel "glad" because Kampung Buntal is beautiful in terms of natural environment, have friendly and cooperative local people, the facilities/ infrastructures are currently improving, has fresh seafood and many other reasons. However, the minimal emphasis on the feeling of "safe and secure" may be due to the close or strong community bonds between the residents of Kampung Buntal. As claimed by Stylidis et al. (2014), residents tend to underemphasise important aspects like safety because $\backslash$ residents usually have a close relationship with their community. Being in such a relationship makes the residents feel more protected and pleased with their overall stay in that destination.

The second highest affective dimension of Kampung Buntal is arousing. In this study context, Kampung Buntal is perceived as an arousing destination because it triggers the 
feelings of "lively" and "stimulating" among the residents. According to Merriam-Webster (2016), "lively" can be defined as a state of feeling active or spirited due to a crowded situation or an atmosphere that is full of excitement. On the other hand, "stimulating" refers to a state of feeling energetic when the place is full of activity (The American Heritage, 2011). Based on the survey responses, most respondents claimed that they feel lively in Kampung Buntal because the village is happening and is often packed by outsiders that come for fresh seafood, as well as sightseeing activities. In addition, they feel stimulating because Kampung Buntal has a lot of fun activities. which include fishingrelated activities, business activities, mini sport activities. as well as tourism-related activities. In line with Guzel et al. (2020), this arousing feeling is influenced by external stimuli that create excitement, joy and so on. External stimuli, in this sense, refer to activities or attractions that instigate specific response behaviours. According to Martin and Bosque (2008), a person will use this affective-image dimension to form their impressions and evaluate the attractiveness of a destination based on their feelings towards a particular destination. Therefore, it is revealed via this study that the village is not a sleepy destination, but instead an arousing destination, which offers an exciting atmosphere and numerous fun activities.

The third affective image dimension of Kampung Buntal according to its residence is relaxing. The relaxing dimension can also be referred to as a state of feeling calm or serene, whereby a person is free from any disturbance (The American Heritage, 2011). In this study, Kampung Buntal is perceived as a relaxing destination as opposed to a stressful destination mainly due to a few factors. Firstly, the nature of cooperative locals in Kampung Buntal promotes a peaceful environment of the village, whereby the community is free from any fights or disturbance. Secondly, the relaxing image dimension may be attributed to the natural environment of Kampung Buntal itself, such as its calm beach, cool comforting breeze that comes from the sea and the village itself, being located far from the hectic life of Kuching city. Drawn from the argument made by Naidoo et al. (2010), the authors claimed that a destination is perceived as a relaxing place when it is surrounded by beautiful environment (i.e beaches) and wonderful local people who offer a calm and restful environment. This argument echoes the current study result, which firmly supports the image of Kampung Buntal as a quiet, relaxing destination.

In addition, it is made clear that none of the respondents described Kampung Buntal as a gloomy place, which indicates that the village is neither boring nor an exciting destination. This study finding somewhat mirrored the work of Rudez (2014), who revealed that Portoroz, a small seaside destination in Slovenia as neither an exciting nor gloomy one. This may be attributed to physical features of Portoroz, which offers more relaxing and pleasant sensations. Similar to Portoroz (Rudez, 2014), Kampung Buntal is only a small fishing village that mostly carries the image of natural environment as part of its unique physical attributes. This explains why $76.97 \%$ of the Kampung Buntal's respondents perceived their village as a pleasant destination instead of an exciting one.

\section{Conclusion}

As Beerli and Martin (2004) claimed, the total destination image is best formed when it comprises cognitive and affective image components. This study revealed the cognitive and affective images of Kampung Buntal from the perceptions of its residence. The top three cognitive image components of Kampung Buntal include dimensions such as natural environment/touristic attraction, local people and ambience, and local infrastructure. Meanwhile, the affective image components of Kampung Buntal are related to pleasant, arousing, and relaxing dimensions, which fall under the category of positive dimension. On the whole, it can be said that Kampung Buntal is highly perceived by its residence as a pleasant destination that offers mostly natural or touristic attractions. 
The empirical findings of this study have shown that the model has successfully identified the effective cognitive and affective image components of a rural destination in the initial formation phase via the use of a projective technique. Using this empirical finding, tourism developers or marketers can have insights of the promotional images that could capture the essence of a destination. It is very critical for tourism developers or marketers to promote a destination using authentic images and communicate it to visitors. From visitors' feedback obtained later, the destination image could then be refined further so that successful destination competitiveness of the rural destination could be achieved in the near future.

This study strongly recommends the formation of a destination image to effectively consolidate the formation of desired and thus approved images of local residents. Consequently, this initial formation process can persuasively encourage active involvement of residents in their own tourism development. Through their active involvement, the current destination setting could be sustained in the best possible ways (Lo et al., 2012).

In future studies, it is strongly advised for image researchers to complete the entire image formation process. Due to a period of short time, this study was unable to complete the entire image formation process of Kampung Buntal. A lack of deep knowledge in qualitative analysis had also limited the quality of data interpretation in this study. Lastly, this study only attempted to seek the positive-affective dimension of Kampung Buntal, which may not reveal the overall feelings of its residents that might comprises of positive and negative emotions as well. Therefore, it is recommended that future studies address these limitations so that the current study could be further improved.

\section{Acknowledgements}

This work is supported by Faculty of Economics and Business, Universiti Malaysia Sarawak (UNIMAS) Kota Samarahan.

\section{References}

Agapito, D., Valle, P., \& Mendes, J. (2013). The cognitive-affective-conative model of destination image: A confirmatory analysis. Journal of Travel \& Tourism Marketing, 30(5), 471-481.

Ayob, N. \& Kichin, S. (2016). Residents' perception as key input to destination image formation for rural tourism. International Journal of Service Managmeent and Sustainability, 1(1), 48-57.

Alonso-Dos-Santos, M., Calabuig, F., Montoro, F., Valantine, I., \& Emeljanovas, A. (2014). Destination image of a city hosting sport event: Effect on sponsorship. Transformations in Business \& Economics, 13(2A), 343-359.

Baloglu, S., \& McCleary, K. (1999). A model of destination image formation. Annals of Tourism Research, 24(4), 868-897.

Beerli, A., \& Martin, J. (2004). Factors influencing destination image. Annals of Tourism Research, 31(3), 657-681.

Bruwer, J., \& Lesschaeve, I. (2012). Wine tourists' destination region brand image perception and antecedents: Conceptualization of a winescape framework. Journal of Travel \& Tourism Marketing, 29(7), 611-628.

Byon, K., \& Zhang, J. (2010). Development of a scale measuring destination image. Marketing Intelligence \& Planning, 28(4), 508-532.

Campelo, A., Aitken, R., Thyne, M., \& Gnoth, J. (2014). Sense of place: The importance of destination branding. Journal of Travel Research, 53(2), 154-166.

Catterall, M., \& Ibbotson, P. (2000). Using projective techniques in education research. British Educational Journal, 26(2), 245-256.

Chalip, L., Green, B., \& Hill, B. (2003). Research and reviews. Journal of Sport Management, 17, 214234.

Chen, H., Chen, P., \& Okumus, F. (2013). The relationship between travel constraints and destination image: A case study of Brunei. Tourism Management, 35, 198-208. 
Chen, C., \& Tsai, D. (2007). How destination image and evaluative factors affect behavioural intentions? Tourism Management, 28, 11151122.

Chen, J. (2001). A case of Korean outbound travelers' destination images by using correspondence analysis. Tourism Management, 22, 345-350.

Conversano, C., Rotondo, A., Lensi, E., Vista, O., Arpone, F., \& Reda, M. (2010). Optimism and its impact on mental and physical well-being. Clinical Practice \& Epidemiology in Mental Health, 6, 25-29.

Donovan, R., \& Rossiter, J. (1982). Store atmosphere: An environmental psychology approach. Journal of Retailing, 58(Spring), 34-57.

Doxey, G. (1975). A causation theory of visitorresident irritants: Methodology and research inferences. The Impact of Tourism: The Travel Research Association, 6th Annual Conference Proceedings (pp. 195-198). San Diego.

Elliot, S., \& Papadopoulos, N. (2015). Of products and tourism destinations: An integrative, crossnational study of place image. Journal of Business Research, 69(3), 1-9.

Elliot, S., Papadopoulos, N., \& Kim, S. (2011). An integrative model of place image: Exploring relationships between destination, product and country images. Journal of Travel Research, 50(5), 520-534.

Emmons, R., \& McCullough, M. (2003). Highlights from the research project on gratitude and thankfulness: Dimensions and perspectives of gratitude. Retrieved from Psychology Miami: www.psy.miami.edu

Fakeye, P., \& Crompton, J. (1991). Image differences between prospective, first-time and repeat visitors to the Lower Rio Grande Valley. Journal of Travel Research, 30(2), 10-16.

Fredrickson, B. (2001). The role of positive emotions in positive psychology. American Psychology, 56(3), 218-226.

Guzel, O., Sahin, I. \& Ryan, C. (2020). Pushmotivation-based emotional arousal: A research study in a coastal destination. Journal of Destination Marketing \& Management, 16, 1-11.

Hanin, Y. (2004). Emotion in sport: An individualized approach. In C. Spielberger, Encyclopedia of Applied Psychology, Three-Volume Set (pp. 745750). Academic Press.

Hosany, S., Ekinci, Y., \& Uysal, M. (2006). Destination image and destination personality: An application of branding theories to tourist places. Journal of Business Research, 59, 638642.

Houck, A. (2007). The development of a music therapy protocol for determining the Spiritual needs of Hospice Patients. Ann Arbor, MI: ProQuest Information and Learning Company.

Hoyer, W. D., \& MacInnis, D. J. (2007). Consumer Behaviour (4 ${ }^{\text {th }}$ ed). Boston: Houghton Miffin Company.

Hufendiek, R. (2016). Embodied emotions: A naturalist approach to a normative phenomenon. NY: Routledge.

Hui, T., \& Wan, T. (2003). Singapore's image as a tourist destination. International Journal of Tourism Research, 5(4), 305-313.

Hunter, W., \& Suh, Y. (2007). Multimethod research on destination image perception: Jeju standing stones. Tourism Management, 28, 130-139.

Huong, N., \& Lam, N. (2008). Grammatical and semantic features of some adjectives denoting happiness- the feeling of pleasure. Journal of Science, Foreign Language, 24, 157-166.

Jaafar, S. M. R. S., Ismail, H. N., Md Khairi, N. D. (2020). Changes of city image in Kuala Lumpur. IOP Conference Series: Earth and Environmental Science (pp. 447). Surakarta, Indonesia.

Kim, H., \& Chen, J. (2016). Destination image formation process: A holistic model. Journal of Vacation Marketing, 22(2), 154-166.

Kujala, S., \& Nurkka, P. (2012). Sentence completion for evaluating symbolic meaning. International Journal of Design, 6(2), 15-25.

Kwon, J., \& Vogt, C.A. (2010). Identifying the role of cognitive, affective, and behavioural 
components in understanding residents' attitudes toward place marketing. Journal of Travel Research, 49(4), 423-435.

Law, E. (1995). Tourist destination management: Issues, analysis and policies. New York: Routledge.

Li, X., \& Vogelsong, H. (2002). A model of destination image promotion with a case study of Nanjing, P.R. China. Proceedings of the 2002 Northestern Recreation Research Symposium (pp. 194-199). Newton Square, U.S.: Department of Agriculture, Forest Service, Northeastern Research Station.

Lin, C., Morais, D., Kerstetter, D., \& Hou, J. (2007). Examining the role of cognitive and affective image in predicting choice across natural, developed and theme-park destinations. Journal of Travel Research, 46(2), 183-194.

Lo, M., Mohamad, A., Songan, P., \& Yeo, A. (2012). Positioning rural tourism: Perspectives from the local communities. International Journal of Trade, Economics and Finance, 3(1), 59-65.

Lopes, S. (2011). Destination image: Origins, developments and implications. PASOS, 9, 305315.

Lubbe, B. (1998). Primary image as a dimension of destination image: An empirical assessment. Journal of Travel \& Tourism Marketing, 7(4), 21-43.

Marino, E. (2008). The strategic dimension of destination image. An analysis of the French Rivera image from the Italian tourists' perceptions. Thesis (PHD). Italy: University of Naples 'Federico II' Faculty of Economics.

Magnini, V., Ford, J., \& LaTour, M. (2012). The role of qualitative methods in tourism $Q O L$ research: $A$ critique and future agenda. Springer: Netherlands.

Martin, H., \& Bosque, I. (2008). Exploring the cognitive affective nature of destination image and the role of psychological factors in its formation. Tourism Management, 29(2), 263277.

Mason, M. (2010). Sample size and saturation in PhD studies using qualitative interviewa. Forum
Qualitative Sozialforschung/Forum:Qualitative Social Research, 11(3), Art.8.

Matthew, P. V., \& Koshy, M. P. (2016). Responsible tourism as a precursor to destination sustainability and quality of life of communities: A study at tourism destinations of Kerala.

Mendes, J., Valle, P. O. D., Guerreiro, M. (2011). Destination image and events: A structural model for the Algrarve Case. Journal of Hospitality Marketing \& Management, 20(3-4), 366-384.

Merriam-Webster. (2016). Definition of Lively. Retrieved from Merriam-Webster: http:// webcache.googleusercontent.com/ search?q=cache:http://www.merriam-webster. com/dictionary/lively

Moutinho, L. (1987). Consumer behaviour in tourism. European Journal of Marketing, 21(10), 5-44.

Naidoo, P., Ramseook-Munhurrun, P., \& Durbarry, R. (2010). Tourists' perspective of the brand image of Mauritius. International Journal of Management and Marketing Research, 3(3), 95106.

Nghiem-Phu, B. (2014). A review of destination image studies from 2008 to 2012. European Journal of Tourism Research, 8, 35-65.

Obenour, W., Lengfelder, J., \& Groves, D. (2005). The development of a destination through the image assessment of six geographic markets. Journal of Vacation Marketing, 11(2), 107-119.

Peter, P., \& Olson, J. (1999). Consumer behaviour and marketing strategy (6th ed.). Boston: McGraw-Hill.

Pike, S., \& Ryan, C. (2004). Destination positioning analysis through a comparison of cognitive, affective and conative perceptions. Journal of Travel Research, 42(4), 333-342.

Pizam, A. (1987). Planning a tourism research investigation. In J. Ritchi \& C. Goeldner ( $2^{\text {nd }}$ Ed.), Travel, tourism and hospitality research. A handbook for managers and researchers (pp. 6376). New York: Wiley.

Prayag, G., \& Ryan, C. (2012). Antecedents of tourists' loyalty to Mauritius: The role and influence of destination image, place attachment, 
personal involvement and satisfaction. Journal of Travel Research, 51(2), 342-356.

Putthiwanit, C. (2012). Investigating consumer insight by using completion techniques: A pilot study of a motorcycle accessory shop in Thailand. International Review of Management and Marketing, 2(2), 92-98.

Qu, H., Kim, L., \& Im, H. (2011). A model of destination branding: Integrating the concepts of the branding and destination image. Tourism Management, 32, 465-476.

Rakic, T., \& Chambers, D. (2010). Innovative techniques in tourism research: An exploration of visual methods and academic filmmaking. International Journal of Tourism Research, 12, 379-389.

Rubin, A., \& Babbie, E. (2010). Research methods for social work. New York: Brooks Cole.

Rudez, H. (2014). Affective Tourism Destination IMage: The case of Portoroz. Tourism and Hospitality Congress Proceedings (pp. 245255). Slovenia: University of Primorska.

Russell, J., \& Pratt, G. (1980). A description of the affective quality attributed to environments. Journal of Personality and Social Psychology, 38(2), 311-322.

Ryan, C., \& Aicken, M. (2010). The destination image gap - visitors' and residents' perceptions of place: Evidence from Waiheke Island, New Zealand. Current Issues in Tourism, 13(6), 541561.

Sansone, R., \& Sansone, L. (2010). Gratitude and well being. Psychiatry (Edgmont), 7(11), 18-22.

Scherer, K. (2005). What are emotions? And how can they be measured? Social Science Information, 44(4), 695-729.

Schroeder, T. (1996). The relationship of residents' image of their state as a tourist destination and their support for tourism. Journal of Travel Research, 34(4), 71-73.

Sirgy, M., Rahtz, M., \& Underwood, R. (2000). A method for assessing residents' satisfaction with community-based services: A quality of life perspectives. Social Indicators Research, 49, 279-316.

Soley, L., \& Smith, A. L. (2008). Projective techniques for social science and business research. Milwaukee: Southshore Press.

Spiekermann, S. (2016). Ethical IT Innovation: A value-based system design approach. NW: CRC Press Taylor \& Francis Group.

Stabler, M. (1988). The image of destination regions: Theoretical and empirical aspects. In B. Goodall \& G. Ashworth, Marketing in the Tourism Industry: The promotion of destination regions (pp. 133-161). Croom Helm, London: Sternberg, E.

Staik, A. (2013). Emotion checklists: Identifying your feelings, pleasant or not. Retrieved from Psych Central: http://blogs.psychcentral.com/ relationships/2013/03/emotion-checklistsidentifying-your-feelings-pleasant-and-not/

Stepchenkova, S., \& Shichkova, E. (2016). Country and destination image domains of a place: Framework for quantitative comparison. Journal of Travel Research, 56(6), 776-792.

Stylidis, D., Biran, A., Sit, J., \& Szivas, E. (2014). Residents' support for tourism development: The role of residents' place image and perceived tourism impacts. Tourism Management, 45(December), 260-274.

Stylidis, D., Sit, J., \& Biran, A. (2014). An exploratory study of residents' perception of place image: The case of Kavala. Journal of Travel Research, 55(5), 659-674.

Tasci, A., \& Gartner, W. (2007). Destination image and its functional relationships. Journal of Travel Research, 45(4), 413-425.

Tasci, A., Gartner, W., \& Cavusgil, S. (2007). Conceptualization and operationalization of destination image. Journal of Hospitality \& Tourism Research, 31(2), 194-223.

The American Heritage. (2011). American Heritage Dictionary of the English Language (4th ed.). Boston: Houghton Mifflin Harcourt.

Upadhyaya, M. (2012). Projective techniques for brand image dimensionality and using various 
techniques to investigate and improve the brand personality. Polish Journal of Management Studies, 6, 89-100.

Valle, P., Mendes, J., \& Guerreiro, M. (2012). Residents' participation in events, events image and destination image: A correspondence analysis. Journal of Travel \& Tourism Marketing, 29(7), 647-664.

Veno, J. (10 January, 2015). DBKU to take over Kpg Buntal esplanade. Retrieved from The Borneo Post: http://www.theborneopost. com/2015/01/10/dbku-to-take-over-kpg-buntalesplanade/

Wassler, P., \& Hung, K. (2015). Brand-as-person versus brand-as-user: An anthropomorphic issue in tourism-related self congruity studies. Asia Pacific Journal of Tourism Research, 20(8), 839-859.

Zhang, H., Fu, X., Cai, L., \& Lu, L. (2014). Destination image and tourist loyalty: A metaanalysis. Tourism Management, 40(February), 213-223. 